Howard. Evans, \& McDonald, 1973). It would be surprising if none of these elements was influenced by the S's imagination. Thus, it is important to note that the results of Experiments I-IV only show that if $\mathrm{FAE}_{\mathbf{s}}$ exists, then it is not as strong as $\mathrm{FAE}_{\mathbf{r}}$ and does not add linearly to it. We are currently attempting to replicate Crebus \& Stadler's (1971) procedures which are designed to isolate $\mathrm{FAE}_{\mathrm{r}}$ and $\mathrm{FAE}_{\mathbf{s}}$ rather than measure the difference between them.

It is also possible that an FAE can be produced by imagining the I circle if the Ss have very good imagery. It would be interesting to replicate the entire set of experiments reported above using idetikers.

\section{REFERENCES}

Cohen, J. Statistical power for the behavioral sciences. New York: Academic Press, 1969.
Crebus, H., \& Stadler, M. Über Wahrnehmungsprozesse in den Coordinaten der Netzhaut und des anschaulichen Raumes. Psychologische Forschung, 1971, 34, 325-342.

Ganz, L. Mechanism of the figural aftereffect. Psychological Review, 1966, 73, 128-150.

Howard, R. B. Neurophysiological models of figural aftereffects and visual illusions. Psychonomic Monographs, 1971, 4 57-72.

How ard, R. B., Evans, G., \& McDonald, J. Induction-, test-, and comparison figure interactions in figural aftereffects and illusions. Perception \& Psychonomics, 1973, in press.

Rosenthal, R. Experimenter effects in behavioral research. New York: Appleton-Century-Crofts, 1966.

Stadler, M. Figural aftereffects as optical illusions? American Journal of Psychology, 1972, 85, 351-375.

(Received for publication August 3, 1973.)

\title{
Maintenance and autoshaping of keypecking in undeprived pigeons*
}

\section{JOHN L. BILBREY†, DONALD D. PATTERSON $\dagger \dagger$ and STEPHEN WINOKUR}

Texas Christian University, Fort Worth, Tex. 76129

Experienced undeprived pigeons pecked for food presentations on a VI 3-min schedule. When the schedule was changed to VI $30-\mathrm{sec}$, response rates increased and behavioral contrast was observed. To investigate the role

*This research was supported by T.C.U. Research Foundation Research Grant PS 6977 to S. Winokur.

+Now at Human Resources Research Organization, Dothan, Ala. 36301 .

+ Now at Jacksonville State University, Jacksonville, Ala. 36265 . of experience with reinforced responding, another three undeprived naive birds were autoshaped to keypeck and showed comparable rates of responding on a VI 30-sec schedule.

Neuringer $(1969,1970)$ reported that food-deprived pigeons responded on a VI 1-min schedule but not on a FR 10 schedule of reinforcement for food, even when food was freely available. Similarly, Carder \& Berkowitz (1970) found that hungry rats would barpress for food when 2 , but not 10 , responses were required. Singh (1970), however, found that rats preferred earned to free food, even when the food was earned on a FR 11 schedule. Experiment I, below, attempted to replicate 
Table 1

Mean Response Rates (Responses Per Minute) of Each Bird for the Last 4 Days of Each Schedule

\begin{tabular}{|c|c|c|c|c|c|c|c|}
\hline \multirow[b]{2}{*}{ Bird } & \multirow[b]{2}{*}{ VI 3} & \multicolumn{2}{|c|}{ Experiment I } & \multicolumn{2}{|c|}{ Experiment II } & \multicolumn{2}{|c|}{ Experiment III } \\
\hline & & Plug & VI 3 & VI 3 & VI $30 \mathrm{Sec}$ & Red & White \\
\hline 3 & 2.27 & 0.58 & 4.83 & 1.99 & 0.00 & 0.91 & 0.00 \\
\hline 4 & 24.59 & 14.27 & 10.96 & 2.85 & 29.35 & 4.21 & 6.27 \\
\hline 7 & 0.92 & 0.13 & 1.96 & 0.12 & 0.00 & 0.41 & 0.00 \\
\hline 8 & 15.32 & 0.71 & 1.96 & 1.06 & 10.19 & 785 & 12.26 \\
\hline 11 & 0.05 & 0.07 & 0.29 & 0.11 & 5.57 & 0.73 & 0.59 \\
\hline 12 & 6.01 & 1.25 & 0.89 & 3.23 & 35.13 & 9.02 & 15.32 \\
\hline 16 & 0.68 & 0.01 & 0.70 & 0.03 & 0.19 & 0.15 & 0.00 \\
\hline 17 & 0.22 & 0.04 & 0.08 & 0.04 & 0.04 & 0.00 & 0.00 \\
\hline Column & 1 & 2 & 3 & 4 & 5 & 6 & 7 \\
\hline
\end{tabular}

systematically the work of Neuringer, and to extend it.

\section{EXPERIMENT I Method}

\section{Subjects}

Eight male Silver King pigeons, which were experienced in responding on a VI 3-min schedule of food reinforcement. were used. The birds had food, ${ }^{1}$ grit, and water available ad lib in their home cages for a month before and during the experiment. except as noted below.

\section{Apparatus}

Two BRS-Foringer operant conditioning chambers, control, and recording equipment of the type described by Ferster \& Skinner (1957) were used. The key of each was transilluminated with a red light (the same stimulus at which the birds had previously been trained to peck).

\section{Procedure}

During the first 14 daily 1 -h sessions of Experiment I, each nondeprived bird was allowed to keypeck on a VI 3-min schedule for food. While each bird was in a chamber, food was available only from the feeder. As a test, a clear plastic plug was inserted into each feeder opening. The plugs prevented the birds from eating while in the chamber, but did not obstruct their view of the food for a period of 8 days. Finally, the plugs were removed from the feeders and the birds were allowed to eat when their responding operated the feeder. This procedure remained in effect for 11 day's.

\section{Results and Discussion}

All but two birds (11 and 17) responded at moderate and stable rates. There were, however, individual differences in response rates among the birds. Column 1 of Table 1 shows mean response rates of each bird for the last 4 days of the first part of Experiment $I$. Column 2 of Table 1 shows mean response rates for the last 4 days when the plugs were in the feeder openings. Column 3 of Table 1 shows the mean response rate of the last 4 days of the last phase of Experiment I. While the plugs were in the feeder openings, the response rates of all birds decreased, but response rates increased when the plugs were removed. This indicates that the birds' pecking was not maintained solely by the sight or sound of food presentations, but by the actual food.

These data also indicate that pigeons will emit as many as 63 responses per reinforcer in the presence of free food. However, individual differences in work output among birds are large, and most birds respond only a few times per reinforcer.

\section{EXPERIMENT II}

To explore further the response-controlling properties of the response-contingent food, and to also explore the effects of varying the schedule requirement, Experiment II investigated the possibility of stimulus control by means of a multiple schedule of reinforcement in the presence of free food.

\section{Method}

In Experiment II, a multiple VI 3-min VI 30-sec schedule was introduced to the $\mathrm{Ss}$ and apparatus of Experiment $\mathrm{I}$. The red keylight was on during the VI 3-min schedule, and a white keylight was on during the VI $30-\mathrm{sec}$ schedule. Each schedule was in effect for $10 \mathrm{~min}$. and the $10-\mathrm{min}$ components were alternated during daily 60 -min sessions.

After the birds had been on this schedule for 12 days, free food was introduced into the experimental chambers in a size $1 / 2$ (tuna) can, which was open at the top. The birds were then induced to eat this food. First, the session was lengthened to $2 \mathrm{~h}$; then each bird was placed on a 23-h deprivation schedule and given a 1-h session in which food was available in the chamber. This session was followed immediately by a 1-h session on the multiple schedule previously described. After 3 days, the preand postsession weights of the birds and food cans indicated that all birds were eating out of the food cans. The birds were then allowed free food in their home cages. and the filled food cans remained in the experimental chambers throughout the remainder of Experiment II (a period of 29 days).

\section{Results and Discussion}

The mean response rate of each bird for each component of the multiple schedule of Experiment II is shown in the Columns 4 and 5 of Table 1. Each mean is that of the rates on the last 4 days of Experiment II. Birds $3,7,16$, and 17 rarely pecked during the VI 30-sec component. None of the eight birds had previously seen the white key, but only these four treated it as an $S^{\Delta}$. Birds $4,8,11$, and 12 displayed moderate rates of pecking during the VI 30 -sec component and decreased rates of responding during the VI 3-min component.

If the data of Columns 3 and 4 of Table 1 are compared, it may be observed that. with the exception of Bird 12, response rates during the VI 3-min component of Experiment II were lower than 
comparable rates during Experiment $\mathrm{I}$. This appears to be a case of negative behavioral contrast (Terrace, 1966). An accurate assessment of behavioral contrast requires a baseline of responding on a multiple schedule of reinforcement with identical components. Experiment III was conducted to provide such a baseline.

\section{EXPERIMENT III}

\section{Method}

During Experiment III, the Ss and apparatus were those of Experiments I and II, but the schedule of reinforcement in the presence of both the red and white keylights was VI 3-min. Component durations were $10 \mathrm{~min}$ in simple alternation, and session lengths were $1 \mathrm{~h}$. Food was available ad lib in the birds' home cages and in the food cans in the chambers. Experiment III had a duration of 26 days.

\section{Results and Discussion}

No change in response rates in the presence of the red light was shown by Birds 3,7 , and 17, who did not respond in the presence of the white light in Experiment II. The other birds showed a gradual decrease in response rates during the white light (previously correlated with the VI 30 -sec schedule) and an increase in response rates during the red light. Columns 5 and 6 of Table 1 show the mean response rate in each component of the schedule for each bird over the last 4 days of Experiment III. A comparison of the entries in Columns 4 and 6 indicates that response rates in the presence of the unchanged VI 3-min schedule were greater in Experiment III than in Experiment II. That is, positive behavioral contrast occurred as shown by decreased rates of responding in the unaltered component when rates of reinforcement and responding decreased in the other component (Terrace, 1966).

These data indicate that experienced undeprived birds will respond for food in the presence of free food on schedules as demanding as VI 3-min and that stimulus control and behavioral contrast, phenomena previously shown only in highly motivated animals, can be demonstrated.

\section{EXPERIMENT IV}

All experiments reported to date have employed strong food deprivation in order to induce Ss to first make the response which produces food on a response-contingent basis (cf. Tarte \& Snyder, 1972). In order to provide some information about the necessity of experience of this sort in the development of willingness to work for earned vs free food, an attempt was made to train three birds to keypeck without depriving them of food.

\section{Method}

\section{Subjects and Apparatus}

Three experimentally naive male White Carneaux pigeons were the Ss. Food, water, and grit were continuously available to the birds' home cages.
The apparatus was the same as that of Lxperiments I, II, and III, except that only one chamber was used.

\section{Procedure}

The birds were exposed to 3-sec presentations of the feeder on a VI 1-min schedule for three daily sessions of $90 \mathrm{~min}$. All birds crouched in a corner of the chamber and did not eat the food from the feeder. The birds were then deprived of food for $22 \mathrm{~h}$ and fed $15 \mathrm{~g}$ of food after each daily session. Feeder presentations were increased to $15 \mathrm{~min}$ in duration, and as the birds began to eat from the feeder the duration of feeder presentations was gradually reduced to $3 \mathrm{sec}$. After 11 days, all birds reliably ate from the feeder and ad lib food was restored to their home cages.

Autoshaping was then instituted; it consisted of transilluminating the key with red light for $5 \mathrm{sec}$, followed immediately by $3 \mathrm{sec}$ of feeder operation. This sequence of events occurred on a VI 1-min schedule. A peck at the red keylight produced immediate operation of the feeder. After each bird began to keypeck, a container of food was placed in the experimental chamber. Each bird was allowed 15-20 pecks on CRF before being switched to a VI $30-\mathrm{sec}$ schedule of reinforcement (VI 1-min for one bird), which remained in effect for 8 days for two birds and 11 days for the other bird.

\section{Results and Discussion}

Two birds began to peck consistently in the presence of the red light after five daily sessions (circa 450 light-food presentations). The other bird began to peck after 11 days, but did not peck consistently until after 14 days (circa 1,125 light-food presentations). The average response rates over the last 4 days of Experiment IV were 2.48 and 1.25 responses/min for two birds and 21.44 responses/min for the other bird (on the VI 1-min schedule). Comparing the naive birds with the experienced birds responding on the VI 30-sec schedule (Column 5 of Table 1), one may see that although the experienced birds tended to respond at somewhat higher rates, the rates of the naive birds are completely overlapped by those of the experienced birds. These data suggest that past experience with keypecking when food-deprived is beneficial but not necessary for undeprived birds to learn to keypeck for food.

\section{REFERENCES}

Carder, B., \& Berkowitz, K. Rats' preference for earned in comparison with free food. Science, $1970,167,1273-1274$.

Ferster, C. B. \& Skinner, B. F. Schedules of reinforcement. New York: Appleton-Century-Crofts, 1957.

Neuringer, A. J. Animals respond for food in the presence of free food. Science, 1969, 166, 399-401.

Neuringer, A. J. Many responses for food with free food present. Science, $1970,169,503-504$.

Singh, D. Preference for bar pressing to obtain reward over freeloading in rats and children. Journal of Comparative \& Physiological Psychology, 1970, 73, 320-327.

Tarte, R. D., \& Snyder, R. L. Barpressing in the presence of free food as a function of food deprivation. Psychonomic Science, $1972,26,169-170$

Terrace, H. S. Stimulus control. In W. K. Honig (Ed.), Operant behavior: Areas of research and application. New York: Appleton-Century-Crofts, 1966. Pp. 271-344.

\section{NOTE}

1. The only food ever used in Experiments I, II, III, and IV was Purina Pigeon Checkers.

(Received for publication August 15, 1973.) 